\title{
Erratum to JEMS (Journal of ETA Maritime Science), Volume 3, Issue 1 (2015)
}

\section{Erratum (ER)}

The article that DOI ID is 10.5505/jems.2015.30074 has an oversight about reference;

Jochen, J., Joos, V. B., Kenneth, S. ve Dirk, C. (2015). Innovative Applications of O.R.: MultiObjective Microzone-Based Vehicle Routing for Courier Companies: From Tactical to Operational Planning European Journal of Operational Research. 242(1): 222-231.

The correct version is given below.

Janssens, J., Bergh, J. V. D., Sörensen, K. ve Cattrysse, D. (2015). Innovative Applications Of O.R.: Multi-Objective Microzone-Based Vehicle Routing for Courier Companies: From Tactical to Operational Planning European Journal of Operational Research. 242(1): 222-231.

The editorial board of the Journal of ETA Maritime Science apologize for any inconvenience that may result from this oversight. 
This Page Intentionally Left Blank 